\title{
Ibn Ata Allah al-Iskandari and al-Hikam al-'Ata'iyya in the Context of Spiritually-Oriented Psychology and Counseling
}

\author{
Selami Kardaş ${ }^{1}$ \\ Muş Alparslan University
}

\begin{abstract}
Ibn Ata Allah al-Iskandari was a Shadhili Sufi known for his work, al-Hikam al-'Ata'iyya. Ibn Ata Allah, known for his influential oratorical style, sermons, and conversations, which deeply impacted the masses during his time, reflected these qualities in all his works, especially al-Hikam al-'Ata'iyya. Along with this, finding information on the deepest topics of mysticism is possible in his works. His works address the basic concepts of mystical thinking, such as worship and obedience removed from hypocrisy and fame, resignation, surrender, limits, and hope. This study attempts to explain al-Iskandari's life, works, mystical understanding, contribution to the world of thought, and concepts specifically addressed in his works, like worship and obedience apart from fame and hypocrisy, trust in God, surrender, limits, and hope. Together with this, the study focuses on the prospect of being able to address al-Iskandari and his work, al-Hikam al-'Ata'iyya, in particular as a resource particular to spiritually-oriented psychology and psychological counseling through the context of psychology and psychological counseling.
\end{abstract}

Keywords:

Ibn Ata Allah al-Iskandari • Al-Hikam al-'Ata'iyya • Spirituality • Psychology •Psychological counseling Manevi Yönelimli Psikoloji ve Danışma Bağlamında İbn Atâullah el-İskenderî ve el-Hikemü'l-Atâiyye

$\mathrm{O} z$

İbn Ataullah el-İskenderi, el-Hikemü'l-Atâiyye adlı eseriyle tanınan Şazelî sûfîdir. Döneminde kitleleri derinden etkileyen tesirli hitabet tarzı, vaaz ve sohbetleriyle tanınan İbn Atâullah'ın bu özellikleri başta el-Hikemü'l-'Atâiyye olmak üzere bütün eserlerine de yansımıștır. Bununla birlikte eserlerinde tasavvufun en derin konularına dair bilgiler bulmak mümkündür. Riya ve şöhretten uzak ibadet ve taat, tevekkül, teslimiyet, recâ ve ümit gibi tasavvufî düşüncenin temel kavramlarını eserlerinde ele almıştır. Bu çalışmada İskenderi'nin hayatı, eserleri, tasavvuf anlayışı, düşünce dünyasına katkısı ve eserlerinde özellikle ele aldığı riya ve şöhretten uzak ibadet ve taat, tevekkül, teslimiyet, recâ ve ümit gibi kavramlar açıklanmaya çalışılmıştır. Bununla birlikte İskenderi ve özellikle el-Hikemü'l-Atâiyye adlı eserinin psikoloji ve psikolojik danışma bağlamı ile manevi yönelimli psikoloji ve psikolojik danışma özelinde bir kaynak olarak ele alınabilme ihtimali üzerinde durulmuştur.

Anahtar Kelimeler

İbn Ataullah el-İskenderî • el-Hikemü'l-Atâiyye • maneviyat • psikoloji • psikolojik danışma

\footnotetext{
1 Correspondence to: Selami Kardaş, Department of Educational Sciences, Guidance and Psycholological Counseling, Muş Alparslan University, Muş Turkey. Email: selamikardas@gmail.com

Citation: Kardaş, S. (2018). Ibn Ata Allah Iskandari and al- Hikam al- 'Ata'iyya in the context of spiritually-oriented psychology and counseling. Spiritual Psychology and Counseling, 3, 115-137. http://dx.doi.org/10.12738/spc.2018.3.2.0011
} 
"If a book other than the Qur'an were permissible to be read in Salah, it would be al-Hikam. "

-Sufi mystics

\section{Introduction}

This study first considers the relationship between psychology and spirituality. Focusing on al-Iskandari's life, works, mystical understanding, and contributions to the world of thought, concepts such as worship and obedience removed from hypocrisy and fame, trust in God, surrender, limits, and hope have been examined. As a result, the possibility is emphasized of addressing al-Iskandari, especially his work, al-Hikam al- 'Ata' iyya[The Book of Wisdom], as a resource particular to spirituallyoriented psychology and psychological counseling through the context of psychology and psychological counseling.

Western civilization and science, being constructed over materialist and positivist values, either ignores or underestimates humans' spiritual dimension because human feelings and states do not fit in a test tube and cannot be measured. In this situation, the science of psychology, with all its capitalist behaviors, thoughts, emotions, and states, remains influenced by the materialist paradigm. The path for utilizing humanity's thousands of years of spiritual accumulation, which is necessary for development, is stuck in the rigid rules of the paradigm. In the absence of any scientific validity, inexplicable speculations have been made about human psychology that say it only conforms to the materialist worldview. Thus perhaps the biggest contradiction of today's age has emerged in the scientific field. The impaired person wants to be fixed by the psychologist, who doesn't believe in their own values, doesn't trust, doesn't comprehend the potential of vertical development, or in brief, doesn't know who they are but still claims to be a psychologist (Merter, 2012).

Modern psychology possesses assertive aims like recognizing and explaining humans. Unsatisfied with this, the science of psychology has the goal of teaching how "normal-abnormal" humans need to be and unfortunately claims to do this without touching upon any of the divine, transcendental, or spiritual (esoteric or internal) dimensions. Psychology ignores the human directions of the divine and transcendental for the sake of adhering to the ideology of the science it tries to apply; it sees humans as a research object and alienates humans by ignoring these dimensions.

The West produces and uses knowledge not for revealing the truth but for dominating the world. This knowledge, which lacks wisdom, harms the world and makes it uninhabitable. Psychology, similarly developed in the West, is also nurtured in the hands of a materialistic and pragmatic control paradigm. How can a science developed this way be useful to humanity or solve people's problems? To give a very 
specific example, the biological origins of behavior are addressed in the first section of nearly all books on introduction to psychology. Psychology first emphasizes the human biological dimension. Namely, the information that emerges related to people is not knowledge that encompasses the whole human; it is knowledge belonging to the sides of humans that can be observed and tested, and is therefore incomplete. In the context of the psychological scientific method, it seems to have come up with an incorrect methodology, like the lack of perception of the blind feeling the different organs of the elephant in Rumi's Masnavi.

Religiosity and spirituality, as harmonizing motivating forces, occupy a significant place in people's lives. Religion and spirituality are not concepts that enter life at specific times or conditions; they are life paths that must constantly be explored, experienced, empowered, and constantly protected (Hill \& Pargament, 2003).The need to believe in and commit to spiritual values have persisted in every society since mankind has existed, apart from the sentiment of the European-centered Enlightenment, the distancing of religious values from the center of life, and the decreased significance and impact of religious and spiritual values in the last few centuries. Together with the role of religious and spiritual values in social life and in humans' daily lives showing variation from community to community, never has the whole meaning disappeared. In this sense, spirituality can be said to have a place and a certain level of impact in each society (Kardaş, 2017).

Even with spirituality as an ancient tradition, its relationship with psychology is still new and because of this, what kind of relationship will exactly exist between the two has not been completely defined. Having said this, the world of psychology can clearly no longer ignore the spiritual dimension of man. While the absolute science of psychology clearly distances people from their problems for a while and provides temporary relief through short momentary reflections, spirituality aims for a state of constant peace. It clearly emphasizes the positive qualities of many religious teachings, philosophical movements, mysticism, great thinkers, prophets, and humans. Additionally, spirituality can be said to have the role of being a serious guide by also considering humans' transcendental dimension beyond the behaviors seen based on the element of existing balance.

Behaviors that are tied to spirituality and religion have a significant effect on the idea of understanding the effect that evaluating psychology and spirituality together has on a person's physical and mental health. Recently the relationships among spirituality, religion, psychology, and science have been uncovered, and much research has been done related to this (Koening, McCullough, \& Larson, 2001). Cross-cultural transitions are found in the effects that increase the relation between religion and psychology, and religious and spiritual issues have become important items on the agenda of cultural diversity (Shafranske \& Malony, 1990). 
Spirituality clearly forms an important part of many people's lives. The fields of religion and spirituality, which have been approached with prejudice in the field of psychology through the influence of its positivist outlook prior to the end of the 20th century, have found themselves room in the psychological literature through the influence of new psychological trends like positive psychology (Pargament \& Saunders, 2007). Just as positive psychology also addresses positive human aspects, spiritual psychology is also a health psychology and human potential. While addressing and defining human psychology, it does not construct the human spirit model based on troubled or diseased habits of the body. It is based on evolving human potentials such as saints, prophets, and artists, or at least a normal human soul prone to progress. Instead of defining the human as a genuine broken neurotic, it places one on a developmental platform that aims to reach refinement and strives to achieve this (Frager, 2009).

As part of the psychological counseling experience, those seeking counseling feel the need to share their spiritual and religious needs with counselors. Spiritual needs, often emphasized in Western culture in recent years, increasingly appear as one of the reasons for seeking psychological help (Karairmak, 2004). In order to fully understand clients during the counseling process, one must emphasize spiritual experiences so that clients' religious preferences and beliefs are also respected. This case also helps in understanding whether or not people feel the need for spiritual interventions. At the same time, clients who have problems in the spiritual dimension and who are troubled possibly might also feel the need to talk in this context. The degree to which a client's religious and spiritual feelings affect their mental states and how these feelings can be used in the counseling process must be emphasized (Richards \& Bergin, 2005).

By adopting a holistic and theoretical view concerning the state of a person, therapists gain the skill of helping and guiding not just one side of a person's life but the whole person. Along with this, spiritual goodness involves psychological goodness and chooses a transcendental view if not a humanist one. Spiritual counseling seeks answers from God, who is transcendent. Spiritual goodness integrates all the dimensions of life with each other, including spirituality (Baldwin, 2003). As part of the experience of psychotherapy, clients might also feel the need to share their spiritual needs with the therapist. Therapists in their practices may likely encounter clients looking for answers to their spiritual needs. The research findings reveal those seeking psychological help to find being spiritually healthy important and to expect these needs to be met while receiving help (Kararmak, 2004).

Opatz (1986) defined spiritual goodness in the forms of willingness to search for the meanings and purposes of human existence, of questioning everything, and of grasping abstract things that cannot be easily explained or understood. A spiritually good person 
seeks harmony between one's inner and outer forces. Maslow (1971) stated spiritual life to be a part of human existence and a defining characteristic of human nature. According to his theory, those who realize themselves transcendentally are at the top of the hierarchy. Chapman (1987) argued the state of spiritual well-being to contain the ability to arrive at the full potential of one's spiritual nature and the ability to discover the basic purpose of life, express it, and be found active. In addition, he specified this state to mean learning to give and receive love, enjoyment, and peace; pursuing a satisfying life; and contributing to the development of others' spiritual health.

For people who give importance to spiritual values and beliefs, these values are necessary conditions for protecting and maintaining mental health. People who place these values at the center of their lives can easily be said to experience less mental distress or more easily overcome periods of depression thanks to their commitment to these values. When feeling weak in the face of external factors and when feeling the need to believe, the sense of refuge in a stronger presence is at the top of the religious-based motivations. When encountering difficulties and troubles, beliefs and values constitute an important enduring point and play an important role in protecting mental health thanks to this (Kardaş, 2017).

When considered with the above, the truth of the importance of Ibn Ata Allah alIskandari's life and thoughts stands out in the context of spiritual psychology. According to him, people must first recognize the self, and should recognize and see the deficiencies and defects of the self. The person who does this will have matured themselves because they will go on the path of atonement. The mortal who knows and sees the self will not be easily fooled because they will be aware of the desires of the flesh. According to alIskandari, one of the most important features bestowed on humans is the sense of curiosity and inquisitiveness. Humans' acquirement of new information and awareness of beauties never before encountered in nature or in life will create a distinct satisfaction in them. In this context and as one of the necessities of psychological well-being, the state of ready discovery finds space for itself in Ibn Ata Allah al-Iskandari's world of thought. In order to realize this, al-Iskandari's life, works, mystical understanding, and contributions to the world of thought, as well as the concepts in his works like worship and obedience away from hypocrisy and fame, trust in God, surrender, limits, and hope, will be discussed in place through a psychological perspective.

\section{Al-Iskandari's Life}

Shadhili Sufi Ata Allah al-Iskandari, whose real name is Abu'l AbbasTaj al-Din Aba'l-Fạ̣l Aḥmad ibn Muhammad ibn 'Abd al-Karim ibn 'Aṭa Allah al-Iskandari al-Shadhili, was the third greatest figure of the Shadhili sect after Abu'l Hasan ashShadhili and his successor Abu'l-Abbas al-Mursi. Named Ahmad, he is remembered with monikers such as Abu'l Abbas Taj al-Din Ahmad and Ibn Ata Allah, becoming 
known and famous through the latter. He was born in Alexandria, Egypt. Because he was born in Alexandria, he also took the moniker of al-Iskandari [the Alexandrian]. His grandfather, Abdul Karim, was a Maliki scribe well-known in Alexandria and violently opposed to mysticism according to what is understood from Ibn Ata Allah's statements in Lataif al-Minan [The Subtle Blessings in the Saintly Lives] (Kara, 2014a).

As can be guessed, Ibn Ata Allah had a good religious education and at the same time also worked in the social and human sciences of his era. He studied fiqh from Nashiruddin ibn al-Munayyir; grammar from Muhyiddin al-Mazuni; hadiths from Sharafuddin Abu Muhammad Abd al-Mu'min ibn Halef ibn Abu'l-Hasan ad-Dimyati; and philosophy, logic, and logos from Muhammad ibn Mahmud al-Isfahani.The effect of this education can be seen in al-Iskandari's works, especially in his foundation of knowledge in the areas of the Qur' an and hadiths. In particular, the verses and hadiths in al-Hikam, his most important work, appear comfortably and diligently used; this work additionally has sound logic and reasoning. While he was against mysticism for a while under the influence of his grandfather in the years when he was recognized as a fiqh scholar after completing his education, he met the master of the Shadhili sect and Abu'l-Hasan al-Shadili's successor, Abul-Abbas al-Mursi, and began continued conversations. Ibn Ata Allah, whose views on Sufism had changed, settled in Cairo where he had probably gone for religious conversations and guidance with the permission of the sheikh. A large religious community had formed round here in which participated the father of Ibn al-Subki, author of Tabaqat Al-Shafi'iyah.Intense debates occurred among Ibn Ata Allah and Ibn Taymiyyah, who lived in Egypt in the same years, and as a result among their followers, as well as rumors that led the way to Ibn Taymiyyah's imprisonment. Ibn Ata Allah al-Iskandari, continuing his life in Cairo, came to a significant position in the sect and began to be known as the third greatest figure of the Shadhili sect, following after Abu'l Hasan al-Shadhili and his successor, Abu'l-Abbas al-Mursi. Through the numerous narrations on the death of Ibn Ata Allah, who had spent his life after this in Cairo, he is accepted as having died on the 13th of Jumada al-Awwal 709 (October 19, 1309) and was buried in Cairo Necropolis (Kara, 1981; Kara, 2014a; Özel, 2014).

Ibn Ata Allah al-Iskandari, known for his religious conversations, sermons, and style of speech that deeply affected the people of the period in which he lived, leaned on the deepest topics of mysticism, giving sermons and writing works on this issue. He constructed his Sufi thinking over basic concepts like worship and obedience removed from hypocrisy and fame, trust in God, surrender, limits, and hope. According to him, deeds and worship are merely some forms and repetitions; the real focus is the secret of sincerity in the heart of man. His words were not spoken with love or the ecstasy of enthusiasm; he spoke by kneading his words with subtle contemplation. Ibn Ata Allah al-Iskandari, emphasizing the condition of being in 
need of God, or more intensely called poverty or neediness, saw science that is one with fear of God as the science with the most goodness (Kara, 2015).

One can see the influence of Sulayman, Harith al-Muhasibi, Abu Talib al-Makki, and Abd al-Karim al-Qushayri in the thoughts of Ibn Ata Allah, who dramatically influenced the Sufi world. Again, the influence of Sufis who lived in various periods, such as Ibrahim ibn Adham, Bayazid Bastami, Sahl al-Tustari, al-Fudayl ibn Iyad, Samnun alMuhib, Sirri Saqti, Harith al-Muhasibi, Rabi al-Adawiyya, Abdul Qadir Gilani, Ibrahim al-Khawass, and Dhul-Nun al-Misri, are seen in is works. The names that influenced him the most can be stated as al-Hakim al-Tirmidhi, Abu Hamid al-Ghazali, and Junayd of Baghdad.His works are known in all Islamic countries, North Africa especially, and other regions where various religions were intensely experienced; for example, al-Hikam al-'Ata'iyya, his most influential work, has been translated four times into English, two times to French, and one time to Spanish. Among the commentators of al-Hikam al- 'Ata'iyya, of whom over 50 Sufis have translated and reviewed, are Sufis from almost every sect (Kara, 1992, 2014a; Özel, 2014).

\section{Al-Iskandari's Works}

Al-Hikam al-'Ata'iyya can be shown as Ibn Abdul al-Iskandari's most important work, consisting of a total of 262 aphorisms in which he identifies his thoughts on almost all topics of mysticism. This is enough for now as one of the main focuses of this study is this work.

Lataif al-Minanis another of his works and occurs in 10 sections explaining the lives and legends of Abu al-Abbas al-Mursi and Abu al-Hasan al-Shadhili through a long introduction where Ibn Ata Allah al-Iskandari explains his views on a variety of mystical subjects. Various editions have been made of this work, which is accepted as the oldest and most important work of the Shadhili sect and has autobiographical qualities. Kitab al-Tanwir fi Isqat al-Tadbir [The Book of Illumination], another of his works, was printed at various times and last published with analyses and notes by Muhammad Ali and Abd al-Ahmed. Miftah al-Falah wa Misbah al-Arwah [The Key to Salvation] describes topics like invoking the names of God, seclusion, oneness, and ingenuity; Tâcûl-arûs el-hâvîlitehzîbi'n-nüfûs consists of the recorded sermons and counsels he made to his followers, was clearly written for the general reader, has comfortable and flowing language, and contains teachings on moral advice and the struggles with physical desires. Other works of his areAllah: al-Qashdu al-Mujarrad fi Ma'rifat al-Ism al-Mufrad, which was written in a spoken style about the entity, names, and actions of Allah and has also been translated to French;Unvânü't-tevfik $f i$ âdâbi't-tarîk, a commentary of poetry beginning with the couplet "The flavor of life is chatting with dervishes" from Abu Madyan al-Maghribi; al-Munajat al-Atahiya, which is composed of 36 couplets working the concepts of trust and surrender; and $a l$ - 
Vasiyyail al-IkhWân al-Iskandariyah, which was in the form of a will that he sent from Cairo to his disciples in Alexandria. The works entitled RisalahFi al-Qawaid Diniyah, Mawaidha, Hizb al-Najat, Risalah fi al-Tasawuf, and Hizb al-Nur wa Tamamu al-Surur [The Litany of Light] are also available, but other works of his, Al-Murakkaile al-Kudsi al-Abka,Muhtasharu Tahdhib al-Moudawana, and Usulu muqaddamati al-Wusul have not survived to the present (Kara, 2014a, 2015; Özel, 2014).

At the heart of the works of Ibn Ata Allah al-Iskandari is the life of worship removed from hypocrisy and fame. By emphasizing the concepts of resignation and surrender, he built his thought structure over these concepts. In addition, his works have evaluations on subtleties, which contemplation in particular brings to people. Another important point that Ibn Ata Allah al-Iskandari emphasized the importance of is the secret of sincerity, which means to aim for Allah's acceptance. He stated it as needing to not trust our worship or behaviors, as worship that consists of forms and rituals to gain meaning through this secret of sincerity, and as sincerity that comes to the meaning of worship and behaviors to the meaning of the soul. When coming to the place of worship, which is considered to cover a small space, one must not ignore the possibility that the heart can be resurrected. He cultivated in his works what we can fulfill in this way through this understanding that our duty of servitude, where in one must be aware of the truth that man's constant self-inability always has need of Allah, is the main purpose. Another topic frequently encountered in his works is the need to acquire wisdom with goodness. He stated that fear of God must be in the heart of the human who possesses wisdom, that only this way can wisdom be used in goodness and provide benefit to people. He reminds that wisdom obtained and used together with fear of God is wisdom of the highest goodness (Kara, 2015).

Clearly Ibn Ata Allah al-Iskandari has influenced many people through the sermons he gave and works he wrote from the period in which he lived up until today. The dozens of commentaries written on some of his works supports this fact. The works of Ibn Ata Allah al-Iskandari can provide better understanding and be more effective reading them with the works Masnavi from Rumi and Alchemy of Happiness and Revival of the Religious Sciences from al-Ghazali.

\section{Al-Hikam al-'Ata'iyya}

Quite a few works are available that are identified with Ibn Ata Allah al-Iskandari, but among the most read of his works in the literature of mysticism he is better known for al-Hikam al-'Ata'iyya. This work can be counted at the same time as his most known and most important.

This work comes from some parts of the letters he wrote to his friends and from a poem written as a fervent prayer, together with 262 very precise statements of wisdom 
about all his elements of Sufism that lead to different areas of mysticism. Hikam, which occurs in the title of the work, is the plural of the word hikmet [wisdom]. Wisdom, which is to retain, restrain, and be aware of the sense of words, signifies words that direct humans to well-being in respect of meaning.

Ibn Ata Allah al-Iskandari presented this work to Abu al-Abbaal Mursi, the head of the Sufi order, and the most controversial issues of the Sufi life and system of thought flow very concisely and clearly in this work with an attentive style. Mystical states like fear-hope, spiritual constriction-reprieve, solemnity-habit, and unity-divergence are explained in the work and emphasized over the definitions, understandings, and relationships of reproach and prayer, attainment and Islamic asceticism, uniqueness of body and uniqueness of the martyr, integrity and prophecy, Allah's dominion and service to Him, the mind and the heart, works and active principles, resignation and initiative, and separation and reunion. This work aims to show the ways of being a spiritually mature person particularly by summarily referring to the moral topics of faith, worship, and mysticism (Kara, 2014b).

Conveying Sufi understanding and morality with short, concise words is a rather old tradition. Therefore, this work has no new mystical interpretation; here the writer first conveys the comments and thoughts that Sufis emphasize in the form of concise words styled between poetry and prose using the Arabic language in the best possible way. While reading a piece of wisdom, one finds answers with wisdoms that come following the question marks that can form in the mind so that a wholeness is gained to the work. The essentials of Sufism are presented through concise words in the work. Whether sometimes with a single sentence or sometimes with a few sentences, the author voices the views of mysticism related to all its terms. Studies on al-Hikam al- 'Ata 'iyya that bring together the wisdoms that additionally refer to the same topics have also been done that allow readers to benefit more from the work by sorting the work this way according to topics (Kara, 2015).

Even if the works have clearly benefitted from previous Sufi classics, no information is given here about them.Al-Hikam al- 'Ata' 'iyya is seen as one of the leading works in the literature on Arabic mysticism. Its complex and significant power is understandable through much of its mystical content; conveying its essence strikingly, this literary work has the feature of being the most important and distinctive. One reason also for the view related to areas beyond mysticism for Al-Hikam al-'Ata'iyya is how it explains topics like worship and behavior openly, concisely, and effectively. This work of his is more than just commentary on Sufi prose or verse from the almost 70 sects; this is also an indicator of how much the work has been accepted in Sufi circles. Sufis have studied Al-Hikam al- 'Ata'iyya for centuries as a book of morality and contemplation, discovered quite new meanings, and made commentaries on their 
commentaries. The existence can be shown of authors who have written many more than one commentary on this work (Kara, 2015; Özel, 2014).

The prayers and litanies included at the end of al-Hikam al- 'Ata'iyya also clearly show the complementary effect of the aphorisms. This work can be seen to realize and verify through prayer the situations and determinations that emerge through the aphorisms. This work relates not just to Muslims; it has also attracted the attention of researchers from other religions and understandings who are interested in Islam and mysticism and who at the same time perform research over these. Al-Hikam al- 'Ata' 'iyya is conducive for being translated into other languages. It has been translated into many languages such as Turkish, French, English, German, and Malay (Kara, 2005).

\section{Mysticism}

Ahmad Sirhindi defined mysticism as "a journey from the appearance of Sharia to the truth of Sharia. In al-Hikam al- 'Ata'iyya in support of this, Ibn Ata Allah alIskandari said, "Deeds are nothing outwardly but a dry shape-repetition; the soul that gives life to them is the secret of sincerity."Mysticism arrives at its essence and truth through the dimensions of shape and repetition in all the feelings, behaviors, beliefs, and worships that the Qur'an and Sunnah expect from humans in Islamic belief. Before getting involved in the struggle to reach truth with the whole self in emotion, contemplation, and sincerity by attempting to apply the rules of Islam and eventually become connected in appearance, mysticism is a spiritual path that struggles to attain perfection (Sayar, 2014).

The section of the time in which al-Iskandari lived is significant in terms of the history of mysticism. This stretch of time was when Ibn Arabi revealed his body view of oneness and wrote his works and Sufi personalities had made important contributions to the significant history of mysticism in various parts of the world. Mysticism had spread all over the world, six major sects had been mentioned, and the sects had come to a state of being able to apply mystical training in this period. Mysticism in Cairo also became an important part of the Sufi culture in this period, in the age when Mamluk authorities were being influenced by mysticism. In this period Cairo had activities for sects such as the Shadhili, Rifa'i, Burhaniyya, and Khalwati. The Shadhili sect also had spread in the Islamic world in this period and had a very important position. If the foundations of this sect were laid by Abul Hasan ash-Shadhili, the actual institution was realized in the time of al-Iskandari. That the two sheikhs before al-Iskandari had not left any works is the reason the Shadhili literature begins with al-Iskandari (Özel, 2014).

Ibn Ata Allah al-Iskandari, having before been an opponent of mysticism, changed his views on mysticism after meeting and having continued conversations with Abu 
al-Hasan, the leader of the Shadhili sect, and Abu Al-Abbas al-Mursi, the head of the Shadhili counterpart; he became the third greatest leader of the Shadhili sect. In his work al-Hikam al-'Ata'iyya, which holds a significant place in the Sufi world with over 80 commentaries, al-Iskandari openly and concisely conveys in this work the most debated topics in the system of Sufi life and thought with an elaborate style. Because the psychology of being a servant and dervish was conveyed so well in this work, the saying "If a book other than the Quran were permissible to be read in Salah it would be al-Hikam." became prevalent in later years among Sufis and in the world of mysticism (Kara, 1992).

Ibn Ata Allah al-Iskandari, who came to be placed with the third most important name in the Shadhili order, was a Sufi recognized and read everywhere who affected the masses especially through his style by crossing all boundaries through the conversations given and works written throughout the history of Islam. The work al-Hikam al'Ata'iyya, which concisely and strikingly explains mystical thinking in particular, has been taught as a book of morality and contemplation for centuries, particularly by Sufis. Every time the book is read, dozens of commentaries can be understood to be written about the occasion for a new awakening in people. Al-Iskandari's thoughts are not just understandable from Sufism and the world of Islam but also from his works that have been translated to Western languages, also affecting non-Muslims. Indeed, P. Nwyia, who translated al-Hikam al-'Ata'iyya to French, said, "Al-Hikam is the last great Sufi formed on the shores of the Nile" (Kara, 2015; Özel, 2014).

The next part of the study will comprise the mystical concepts closely related to human life that occurred in the works of Ibn Ata Allah al-Iskandari. Investigating these concepts from the perspective of the Sufi world and al-Iskandari will be attempted especially in the context of al-Iskandari's al-Hikam al- 'Ata'iyya.

\section{Willpower and Discretion}

Willpower has been an important concept as much as it has been able to cause Islamic thinkers to have ideas that differ from one another throughout history. The will of Allah and human willpower have come to be debated by various philosophers and conversationalists in terms of the areas of potential, possibility, and activity. Islamic philosophers have made definitions close to one another on willpower and have stated it to form from inclinations, interests, and enthusiasms. Human willpower is based on the foundations of it psychological existence. Will is formed in humans towards that thing they encounter and desire. This willpower is a natural element existing in humans. Discretion, together with willpower, is one of the basic concepts that form alIskandari's world of thought. He can be said to be the first to conceptualize "discretionary abandonment" in Sufism and the most competent person in this context. Al-Iskandari's conceptualization of discretion needs to be studied properly; according to him, people 
think discretion is under their own life's control, and this is an incorrect attitude. What al-Iskandari means by discretion is that people have the delusion that one's own life has a similar sovereignty as Allah's in the universe. According to al-Iskandari, making plans about life that need to be abandoned is not the continuance of daily works; it is the thought that life and all the events that will be experienced in the future are under one's control. In other words, humans must struggle but should not be closed off to concerns about the result of the work they do. This is intention before discretion, and he defends the idea of needing to abandon this. Al-Iskandari's understanding of discretion needs to be identified primarily in relation to the future. According to him, discretion is like a war with fate. In this context, the desire to determine the outcome of a job while doing it is an unhealthy situation that also damages belief in the absolute authority of Allah. In the true understanding, having faith requires abandoning discretion. According to al-Iskandari, surrender to Allah in the true sense can occur only through abandoning discretion, and this also brings with it faith in the absolute authority of Allah. In this way, the servant will place one's trust in Allah and the soul will also be calmed. Being shut off from worry about the future is a diseased situation that needs to be abandoned. Remembering again that what al-Iskandari means by discretion is discretion that arrives at conflict whether secretly or openly with the absolute discretion of Allah; otherwise maintaining daily life and planning and applying activities for this are acceptable and even necessary situations (Özel, 2014).

His thoughts on willpower and discretion in al-Hikam al- 'Ata'iyya are complete aphorisms. He states that while the benefit of Allah connects to causes, leaving them and withdrawing to seclusion is a secret desire and with this, if Allah saves humans from these causes and brings them to a different point, clinging again to causes will be the cause for estrangement from Allah. He defined the obsession of setting up world affairs and taking continuous precautions for these to be meaningless; these discretions are related to divine will and dependence. He reminds also that in each of the nafs that humans consume in life, a situation exists that Allah has ordained for them. Again we learn from al-Hikam al- 'Ata 'iyya that searching for things other than reaching Allah means being exactly unable to find it, and fearing to lose things other than Him means not reaching Him. As a result, the fact that everything is based on divine will and divine will is based on nothing is like the summary of this heading (Al-Iskandari, 2015).

\section{Mind and Heart}

The mind does not have an exact definition in al-Iskandari's world of thought. However, what he states regarding the mind and the meaning that he added through the mind do not differ from the main axis of the Sufi world. The mind can be accepted as one of the most precious gifts for humans. Through the mind, Allah distinguished humans from other living things and made them superior. However, the pure mind 
can only recognize Allah up to a point, and this is not enough. Al-Iskandari defends the need of the mind to be mingled with the spiritual. Whoever possesses a mind will be illuminated, mingled with the spiritual, and come to a good level through the mind by abandoning discretion and being content with fate. Those who can realize this are those worthy of being characterized as possessing reason. The heart, being another concept, is an ability that occurs often in the Qur'an; it thinks, understands, and contemplates differently than the mind and also contains emotion and intuition. According to al-Iskandari, the heart is not an organ made up of flesh; it is a means of reaching Allah by being cleaned and purified. Cleaning the heart is also possible by disciplining nafs. Al-Iskandari can also be said to have held reason above the heart, together with the truth that the mind and heart can sometimes be used in place of each other. While understanding is possible with the heart, the cognition provided through the mind makes intelligence superior (Özel, 2014).

In al-Hikam al-'Ata'iyya, according to al-Iskandari, this knowledge, which has goodness together with fear of Allah, is a light that illuminates the world of man's heart and that opens the surface of the heart together with the self. He specified that expecting everything but Allah to be cleaned from the heart is not healthy and will prevent man from being connected with Allah. He recalls that the seed of greed in the fields of the heart needs to not be sown and that this will cause the trees of humiliation to sway its branches. It is like the states and situations found within human language. Whatever emerges from the heart also depends on what pours out from the tongue. Words leave the heart wearing the clothes of the heart and come to the tongue. The words that emerge dressed with the light of the heart can be beneficial outside too. The divine lights that come to the human heart abandon and allay the heart by appearing full of empty works other than Allah; therefore, one must empty the heart of world-related delusions for Allah to fill the heart with wisdom and secrets. Lastly, we can say al-Iskandari determined the enlightenment of hearts is as certain as the enlightenment of the sky in this world, only it will emerge in heaven, and its value will only be fully known there.

\section{Nafs}

Different definitions are available from Islamic thinkers and philosophers on the word nafs, which occurs quite often in the Qur'an, mostly in the meaning of "self." AlIskandari stated nafs to have an essence that bears the qualities of liveliness, feeling, will, and motion that are steam natured and soft, and he saw nafs as a tool between the heart and body. Al-Iskandari, who did not emphasize the characteristics of nafs apart from this, accepted nafs as possessing negative characteristics and implied qualities like nurturing, producing, feeling, enthusiasm, and movement, which he defined as animal nafs with it. Nafs that should be qualified as incapable, weak, and poor 
in the face of Allah's might need to be disciplined. According to al-Iskandari, who separated the degrees of nafs in three through the concepts of Nafs-ul Ammara (the commanding self), Nafs-ul Lawwama (the blaming self), and Nafs-ul Mutmainnah (the contented self) which also occurs in the Qur'an, the first two degrees must arrive at Nafs-ul Mutmainnah by being enfolded. He reminds us also with this fact that the degrees are not destroyed, just weakened before being grafted together. He specified one must struggle to arrive at Nafs-ul Mutmainnah, the third degree beyond the first two, and reaching this level is also possible only by surrendering fully to Allah and abandoning discretion (Özel, 2014).

Al Iskandari (2015) in his work al-Hikam al-'Ata'iyya argued that people not complaining about their own nafs and giving in to their wants will give rise to ignominies; however, not consenting to one's nafs and continually reproaching them are sources of virtue. Even though the life of the world looks quite good, beautiful, and attractive from outside, people with open eyes and hearts know it is troubled, ugly, and a testing place. While the nafs always fall for the ornaments of the world, which look beautiful from the outside but in fact make people perish, the heart sees the troubles within and avoids inclining toward the world; by considering what comes later, it takes heed and arrives at salvation. People need to discredit their nafs due to the negative attributes they possess whether or not they fall for praise from others due to certain characteristics. Noble is the praise in the presence of Allah, as opposed to the praise of people which has no benefit, increases pride and reinforces evil. Human nafs constantly want to receive pleasure; alongside taking pleasure in negative situations and sin, one also has pleasure gotten from being proud of the worship one does and earning praise from others, and this is more dangerous. This is why constant nafs should be held to account and controlled. The criterion al-Iskandari revealed in the case of choosing one of two tasks is quite striking: when one needs to choose, one should choose what becomes difficult for the nafs because the task that becomes heavy to the nafs is the right one. Lastly, one reason also for the sensual lusts and heedlessness that comes over humans is for knowing and understanding the value of peace one can feel in the heart that Allah has bestowed on humans.

\section{Asceticism (Zuhd)}

What is meant by giving up feeling interested in something comes to mean distancing from the world and from the sources of pleasure in the world in the context of mysticism. It is one of the most mentioned concepts in mysticism. Different definitions are available related to asceticism: while some Sufis state it to be an act that needs to be performed against forbidden things, other Sufis argue that asceticism done against forbidden things and asceticism done against obligatory and acceptable things are separate virtues. The position that al-Iskandari emphasized the most can 
be said to be asceticism. Al-Iskandari, like other Sufis, specified that diving into the world and moving according to the nafs' wishes are objectionable. Asceticism as he defined it is struggling to accomplish what Allah wants with all people: complying with His commands and being in His service. Along with this and differently from other Sufis, he emphasized the importance of not having to need asceticism as an enemy to this world but as being dedicated to Allah. In his opinion, asceticism does not need to be an enemy to the world, the reason for this also being the world does not exist independent of Allah; on the contrary, it is a reflection of His manifestation. Instead of the world being an enemy to life, one needs to work at identifying Allah without taking it more seriously than necessary. One should not flee from the world but at the same time one should not be secularized nor place the love of the world in the heart. Benefitting from the blessings of the world does not harm the human heart after bringing it to a place of thanks; in fact, if these blessings enable one to realize thanks more healthily, it is a situation of preferring to experience blessings more. In summary, al-Iskandari stated that instead of rejecting blessings to punish the nafs, spiritual maturity will be realized through the conditions of not placing the love of these blessings in the heart and being thankful for them (Özel, 2014).

Al Iskandari (2015) in his work al-Hikam al- 'Ata'iyya, specified the occurrence of world life, which does not exist in reality but consists of darkness and troubles, as a divine torment that inhibits understanding of the existence of Allah. Allah is not veiled; people need to get rid of carnal characteristics to reunite with Him. The mortal qualities of people that are incompatible with the characteristics of servitude distance one from Allah; one accepts Allah's invitation by being stripped of these and becomes close to Him. Together with this, not making friends with people who do not guide people to Allah through their conditions and experiences and whose words do not show the divine path is a healthier situation. When a person needs to ask for something from Allah, realizing what one wants from people is important. The closeness that Allah bestows on one and manifests in one's heart while doing something for Allah and worshipping Him is a sufficient reward for the person. Allah wants people to contemplate everything that they need to learn in the world; $\mathrm{He}$ stated humans will understand His existence this way and promised that seeing God unveiled will occur in heaven. One needs to remember and be aware that Allah is the real friend, is the friend of believers in spite of their shames and imperfections, and is the One who loves them without benefit. One who connects with extreme love becomes its servant and slave, where nothing is wanted more than it; however, Allah does not want one to be a slave to anyone other than Him. Like one who turns to Allah will not bring a thing to Allah, turning away from Him detracts not one thing from His glory. Reaching Allah means to recognize and possess knowledge about Him, otherwise it excludes something arriving at itself and standing with something. In summary, al-Iskandari stated that people need to struggle to realize what Allah wants, 
and the greatest deprivation is also to not turn to Allah when finding opportunities from the occupations and works of the world and to not go to Him when material obstructions are diminished.

\section{Patience and Thankfulness}

According to Sufis, patience has two types: having patience in neediness with obligatory patience, which exists for fulfilling obligations and for avoiding harm, and having patience in vain, which is shown towards distress and calamities in the moments they first emerge. In parallel with this, Al-Iskandari also separated patience in three: patience towards tasks that need to performed, patience towards what is forbidden, and patience towards tribulations. The way of the servant to gain the favor of Allah is possible by showing patience towards difficulties and hardships together with giving thanks in the face of blessings, complying with commands, and staying away from what is forbidden. Being patient and persistent without being filled with despair is important while struggling in the way of Allah. Thankfulness to Allah is also an important concept alongside patience in Sufism. Thankfulness to Allah fosters gratefulness toward Him and is the awareness that blessings come from Him. Thankfulness to Allah is not a blessing; it sees who gives the blessing. According to al-Iskandari, if blessings refer to the self, than being thankful drops to people. Al-Iskandari gathered thankfulness into three classes: tongue, organs, and heart. Thankfulness is realized by acknowledging blessings with the tongue, by obeying Allah, by accepting with the heart that the blessings in anyone's self or in any human comes from Allah, and believing in this. Thankfulness that is with the heart accepts that the creator of good things is Allah. Accomplishing this is also only possible through ingenuity. To summarize, ingenuity, which is the ultimate goal Sufism desires to achieve and is known as an enlightened state, comes to mean seeing something as it is in itself and its adjectives, understanding the shape of its real existence and essence, and knowing Allah to be the goal of human creation. Knowing Allah is exclusive knowledge. Only Allah knows Himself in the genuine meaning. Those who have reached the rank of ingenuity are those who are witness to not knowing Allah and being unable to know Allah, and that only He knows Himself. As mentioned earlier, staying away from the world and its blessings and taking a hostile stand to these is not proper according to al-Iskandari and the Shadhili order he affiliated with. Instead one must be thankful for favorable blessings and believe that this thankfulness is a way of reaching Allah (Özel, 2014).

In al-Hikam al- 'Ata'iyya, al-Iskandari reminds that people must not be surprised at the sadness and troubles they encounter in the life of the world, and these are states where the pleasure of Allah will absolutely be experienced. Each one of the things that Allah has forbidden to humans is for the beneficence of man. Allah not 
giving man some of the things he wants is beneficence, just as giving is. Beneficence is to believe a situation is positive in which the thing the slave wants to receive does not happen. If a lasting honor like being connected or surrendered to Allah is desired, one must not be tied to the blessings of the world that are temporary and must not hope for help from them. What is desired from servants is to know Allah through His Attributes; in giving something to man or not giving His bestowment, $\mathrm{He}$ shows His power, and in both cases He makes Himself known to the servant and also delivers what befalls the servant. Knowing that the problems humans encounter come from Allah must be conducive to alleviating the pain of that tribulation. However, people should believe they will see an absolute favor from Allah after experiencing troubles because the likelihood of positive situations being hidden in the things we do not enjoy have been reported in the Quran by Allah. When something is requested from Allah, if the request does not occur the mature human must conjecture by not objecting to Allah and considering this to have more goodness. The distressing situations and helpless times that humans are found within are the times that also require being closest to Allah. In such cases, faith that salvation will only come from Allah will be conducive to getting through a troublesome situation. Those who have arrived at spiritual maturity are more afraid of being inside of blessings because they worry about complying with the nafs' wants, and hence being removed from and expelled from this state. Fear of Allah, however, makes them connected with Allah. The world, being a world of examination full of troubles, must be turned on occasion to reach Allah. The unaccepted prayer should not make people hopeless in cases where urgency is in the prayer because Allah assures acceptance in the time of His own choosing, not when humans choose; therefore, one must believe that the time for unrealized requests has not yet come. A servant who obeys Allah's commands and consents to the troubles and calamities that He gives is an indicator of Allah having given a blessing to the servant. Also regarding thankfulness, al-Iskandari stated those who are not thankful for the blessing they have obtained will lose those blessings, and those who are thankful attribute the blessings to themselves. All the blessings that people have on earth come from Allah, and thankfulness should only be made to Him; feeling thankful to people for obtained blessings is not a healthy situation. When a person encounters a blessing, they are comforted and loved, and in the moment of trouble that becomes tight; if one feels sorrow, this means one has not matured in a spiritual sense. The person who knows not the value of a divine blessing only understands that value by losing the blessing; therefore blessings need to be duly thanked. People should additionally be in fear of not being able to be thankful for the encountered blessings because this illusion is one of the states that prevents thankfulness and lessens its value (Al-Iskandari, 2015). 


\section{Fear and Hope (Al-Khawf and Al-Raja)}

Al-Khawf is the fear felt toward Allah. This fear acknowledges Allah and can also relate to being afraid of falling into sin, as may happen when withdrawing from His chastisement. Al-Iskandari distinguishes this fear into two. One is the fear of going to hell and through this self-interest it is a fear related to self-pity and self-worry. The other type of fear relates to spiritual situations bestowed by Allah being able to be disrupted by rebelling and not be accessible again. Al-Raja means to be hopeful. One sees the blessings that Allah has bestowed and the heart finds peace by feeling the closeness of Allah. Al-Iskandari indicated al-Raja is unable to suffice on one's own but must be supported by deeds; otherwise al-Raja remains nothing but a baseless expectation. The path to al-Khawf opens in those who look at their own worship and behaviors because these are insufficient in the face of what Allah has given. Together with this, one sees the blessings from Allah across from their own inadequacy; if one understands, this person arrives at the station of al-Raja (Özel, 2014).

Al-Iskandari (2015) stated in al-Hikam al-'Ata'iyya that it is nothing more than the delusion that takes the human prisoner; for humans, being content with what one has is an inexhaustible treasure. If one wants the door of al-Raja to be opened to the self, one must consider the blessings that come from Allah; when one wants the door to al-Khawf to be opened, one must ponder the misdeeds that have been cultivated. Al-Khawf and al-Raja should be thought of as the two scales of a balance; together with the truth that the mercy of Allah exceeds His wrath, the state of al-Raja should be remembered as being of a superior degree than al-Khawf. That humans constantly keep these two states in mind is important; the existence of ayahs in the Qur'an heralding paradise as well as of ayahs that horrify through hell makes constant roaming between and keeping one's eye on these two states necessary.

\section{Resignation and Trust in Allah}

Resignation is defined as the servant believing in Allah's justice with respect to one's fate, calming the heart in the face of what one experiences and finding tranquility. Surrendering the heart is seen within many of the definitions made related to resignation. Resignation means to abandon precautions, to rely on Allah on the point of reasons, and for the heart to be soothed toward the choices of Allah. According to al-Iskandari, the person in the position of resignation consents to what Allah sees suitable for the self and has no choice for the self. According to al-Iskandari, this position is therefore one of the highest ones because in here the person is not one with self-want but with what Allah wants from the person (Özel, 2014).

Al-Iskandari stated in al-Hikam al- 'Ata'iyya that human works do not pass beyond Allah and must not exceed it. The servant should not direct need to other than Allah and should turn only to Allah, not to another for a need that Allah has given. A person 
should not exaggerate the sins they've committed more than necessary and must remember that Allah's forgiveness is greater than sins. The human is free of the thing that shuts out one's hope and is slave to the thing that nurtures hope. The greatest honor for humans is freedom and the lowest state is dependence; it brings together the freedom to be content with the slavery to covet. Therefore the healthiest path is to liberate and be only the servant of Allah without connection to anything else. That the servants of Allah abstain from evils and lusts is a great revelation. Sometimes while the blessings Allah bestows on His servant can distance one from Allah, what He gives can also detach one from the world and can cause one to worship and return to one's self. The human who does not abandon discretion or trust in Allah always thinks about what job to do; on the contrary, the intelligent human has the thought "What will Allah do to me" and expects the action that Allah sees appropriate for the self. One must not fall into doubt from a deed where the human is unable to find peace and must not be hopeless that it will not be accepted because even though a person has not received spiritual compensation in that moment, that deed may have been accepted. As seen, al-Iskandari stated that humans must accept the things that Allah appreciates, see them as appropriate for the self, and must show resignation.

\section{Repeating the Names of Allah (Dhikr)}

Dhikr is given a distinct importance in Sufism and is shown as the most basic worship. Al-Iskandari can be said to be one of the Sufis in the world of mysticism who give the greatest importance to dhikr. According to al-Iskandari, dhikr has a distinguished place when compared to other worships; while time and quantity are specified for all other worship, this is not valid for worshipping with dhikr. Al-Iskandari, who said measuring is necessary in futile worship, stated that it must be remembered as a sign of the love of the beloved by advising humans to increase dhikr. Recalling dhikr's dictionary meaning in Sufi practices is mostly through ascription expressions or the names of Allah in the form of repeating certain name or word groups a specific number of times. Al-Iskandari also counted contemplation on the power of Allah among dhikr, alongside but not limited to remembering the names, attributes, and works of Allah and recalling prophets and saints through prayers. Dhikr means the person prevents their heart from forgetting Allah. According to al-Iskandari, who classified dhikr through specific ranks, the lowest degree of dhikr is made with the tongue and is done mostly habitually without enabling presence of heart. In the right sense, dhikr should not be abandoned just for this; if one never remembers Allah, remembering just with the tongue is seen more appropriate. The second degree of dhikr is done with the heart by enabling divine peace in the heart. It is done by remembering Allah by feeling. In dhikr, the highest degree is dhikr made with the soul, and this dhikr happens through concentrating on Allah by stripping what one has done from one's self and from the dhikr; nothing exists except Allah for the servant in this process. As seen, dhikr is one 
of the most important worships on the path of mysticism and one of the actions that brings one closest to Allah (Özel, 2014).

The easiest and shortest path to reaching Allah is dhikr, therefore humans should make dhikr of Allah in all cases in which they are found. A person should not abandon dhikr saying the heart can't find peace, because unawareness for the sake of dhikr is a better point than the unawareness found within by not making dhikr. Saying getting away from dhikr means getting away from Allah with the heart and tongue; although the heart doesn't feel at first, dhikr made with the tongue is the pretext to the awakening at the end of it, awakened dhikr reaches the dhikr made with presence of heart, and this also brings the human to a space with Allah by being freed from the preoccupations of the whole world. Making dhikr with the tongue and heart, which is a kindness of Allah to humans, is a very important grace for humans; more important than this dhikr is the servant making dhikr and giving praise on the floor of Allah. The condition of dhikr to Allah is a path that leads to Allah making dhikr of the servant, and the dhikr of Allah is without a doubt the greatest dhikr. Allah's remembrance of His servants is certainly greater and more raised than the servant's remembrance of Him (Al-Iskandari, 2015).

\section{Affection/Love}

Love through affection or other names is one of the basic topics of Sufism. I have chosen the word affection due to being a concept al-Iskandari used. Affection is defined in two different ways, as the servant sensing Allah and as Allah sensing the servant. Al-Iskandari defined another affection that is sensed in Allah as not preferring Allah. In the right meaning, the heart that is loved is filled only with what the beloved loves and the desires of what it loves. Allah not leaving anything else from the heart of His servant and from Himself and resolving the love of creation is a grace of His. The servant should frequently remember Allah as a demonstration of love. For the mutual affection between the servant and Allah, al-Iskandari stated that the servant's feeling affection for Allah is in fact the source of Allah feeling affection for the servant; namely, the one who loves is in fact the beloved. Hence, the servant can be said unable to even claim to love Allah; the true owner of love is Allah and loving Allah is possible by at the very most being worthy of Allah's love. According to al-Iskandari, affection has degrees. "Love for Allah" is the beginning degree; preferring Allah to others is to not prefer others to Him. Continuing dhikr is an indicator of this degree. "Love for the sake of Allah is an intermediate degree; the friend of Allah loves others. The servant who is worthy to Allah loves others at all times, which is an indicator of this degree. Another intermediate level is "Love with Allah." The servant loves what Allah loves by ignoring one's own wants. The light of Allah sufficing humans has the portents of this rank. The final point to reach in affection is "Love from Allah." The servant of Allah keeps from everything residual 
and only loves Allah. Its indication is Allah drawing the servant to Himself, so that everything outside of Allah is veiled to the servant. Affection, which al-Iskandari separated into four degrees, is a process that in summary, leads to Allah, prefers Him over all other things, and allows one as much as passing beyond the self through His light. Affection is not from the servant to Allah but direct from Allah to the servant; in other words, affection in its real meaning occurs as a result of the affection Allah feels for the servant (Özel, 2014).

According to Al-Iskandari (2015), some of Allah's servants are chosen for worship, others are also distinguished for affection. While those chosen for worship take the path on the way of Allah through their organs, those chosen for affection serve Allah with their hearts. The two grades will also find their reward at the side of Allah. The conditions of servitude are to not give value to people's interests by not giving importance to what others think about us and to move with what Allah actually finds appropriate for us. If Allah is known and recognized, seeing Him in everything is possible. Whoever cuts off one's connection with Allah becomes lost; one who knows and recognizes Him chooses nothing else. Whoever expects or wants something from His love means they love in the real sense. The one who loves should give everything without expectation or desire to gain the satisfaction of the beloved. For that person, the greatest gain is pleasing what one loves. Humans should gather everything they feel onto one point and should not be interested in anything other than Allah; one can only show true affection this way.

\section{Results}

When we consider societies condemned to modernity and the troubles people experience who live in these societies, we can see it brings more earnings, consumption, happiness, and possessions together with the social problems of greed, envy, and competition and carries society to a serious point of corruption. On this point, a harmonious balance can be said needed among the real ego, the ideal ego, and the required ego for humans to be healthy. This balance and harmony deprived of spirituality cannot be achieved by people ignoring their transcendental dimension. Contradiction or disharmony between the real ego and ideal ego causes anxiety in the individual, widening the distance between the true ego and the required ego causes feelings of guilt, and the required ego moving away from the ideal ego causes inconsistency to be experienced in the individual. In order to catch true peace, the triangle that the real ego, ideal ego, and required ego form needs to shrink; in other words, a balanced approach needs to be provided to each one of the egos.

By taking away from all of this, spirituality, mysticism, and in particular the views, teachings, and works of Ibn Ata Allah al-Iskandari can be said to be quite useful 
on the point of providing this balance and harmony. Modern psychology possesses ambitious aims, like knowing and explaining humans, and unfortunately claims this without any consideration of the divine, transcendental, or spiritual (esoteric, internal) dimensions. On this point, integrating the traditions and accumulations that these dimensions also include will resolve a major shortcoming in this field. Al-Iskandari's views such as acceptance, surrender to fate, and abandoning personal discretion and appreciation in the face of God's discretion and appreciation can lead to very beneficial expansions in the context of creating balance among the real, ideal, and, required egos in the anxious and obsessed modern human. Particularly in his work, al-Hikam al- 'Ata'iyya, the delineations about the psychology of being human and being a servant are summarized through quite powerful wording. The wisdoms expressed here are quite the indicators of the path for ensuring humans' own spiritual development and maturity; the wisdoms, which not only form worship and deeds but at the same time relate to how life must be looked at, are quite effective at guiding humans' own experiential processes.

For any human, person interested in the science of psychology, or employee providing professional counseling services, I am of the conviction that scrutinizing the views, teachings, and especially the works of Ibn Ata Allah al-Iskandari will bring significant expansions to these groups and begin a new process of spiritual development for them. Principally, counselors' attempts at understanding the works and views of al-Iskandari can provide serious contributions to them in the effort to adapt these to their own lives and contribute to their spiritual development. In particular, counselors who have passed through this process can be said to positively affect the processes of spiritual development of clients who come for help and are spiritually oriented. Evaluating the problems clients bring to the counselor together with spiritual and mystical concepts will decrease the severity of the problem and provide significant contributions to the individual's mental health, psychological well-being, and spiritual well-being.

\section{References}

Al-Iskandari, Taj al-Din Abu-l-Fadl Ahmad ibn Muhammad ibn 'Abd al-Karim ibn 'Ata Allah. (2015). Tasavvufi hikmetler hikem-i atâiyye. M. Kara (Ed.). İstanbul.

Baldwin, D. C. (2003). Spiritual identity: Evaluating a seminar on spiritual identity on spiritual wellness. (Unpublished doctoral dissertation). Southern Christian University, OK.

Chapman, L. S. (1987). Developing a useful perspective on spiritual health: Love, joy, peace, and fulfillment. American Journal of Health Promotion, 1, 12-17.

Frager, R. (2009). Manevi rehberlik ve benötesi psikolojisi üzerine yaklaşımlar. İstanbul: Kaknüs.

Hill, P. C., \& Pargament, K. I. (2003). Advances in the conceptualization and measurement of religion and spirituality: Implications for physical and mental health research. American Psychologist, 58(1), 64-74. 
Kara, M. (1981). Şazeliye tarikatı ve üç büyük şeyhi. Hareket, 186, 23-35.

Kara, M. (1992). Şazeliye literatürü üzerine bir deneme. Uludağ Üniversitesi İlahiyat Fakültesi Dergisi, 4, 19-28

Kara, M. (2005). Dervişin hayatı Sufinin kelamı. İstanbul: Dergah Yayınları.

Kara, M. (2014a). İbn Ataullah el-İskenderi. In Türkiye Diyanet Vakfi İslam ansiklopedisi (pp.337338). Ankara: Türkiye Diyanet Vakfi.

Kara, M. (2014b). el-Hikemü'l-Ataiyye. In Türkiye Diyanet Vakfi İslam ansiklopedisi (pp.502503). Ankara: Türkiye Diyanet Vakfi.

Kara, M. (2015). Giriş. M. Kara (Çev\&Ed.). In Tasavvufi hikmetler: hikem-i ataiyye. (pp.11-16). İstanbul: Dergah.

Karaırmak, Ö. (2004). Tinsel anlayışın psikolojik danışmadaki rolü. Türk Psikolojik Danışma ve Rehberlik Dergisi, 3(22), 45-55.

Kardaş, S. (2017). Sanal kimlik ve spiritüel iyi oluşun üniversite ögrencilerinin narsistik eğilimlerini

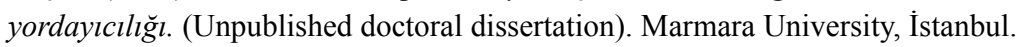

Koenig, H. G., McCullough, M. E., \& Larson, D. B. (2001). Handbook of religion and health. New York, NY: Oxford University Press.

Maslow, A. H. (1971). The farther reaches of human nature. Arkana/Penguin Books.

Merter, M. (2012). Dokuz yüz katlı insan. İstanbul: Kaknüs.

Opatz, J. P. (1986). Stevens Point: A longstanding program for students at a Midwestern university. American Journal of Health Promotion, 1(1), 60-67.

Özel, A. M. (2014). İbn Ataullah El-İskenderi Hayat, Eserleri, Görüşleri. İstanbul: İnsan.

Pargament, K. I., \& Saunders, S. M. (2007). Introduction to the special issue on spirituality and psychotherapy. Journal of ClinicalPsychology, 63, 903-907.

Richards, P. S., \& Bergin, A. E. (2005). A spiritual strategy for counseling and psychotherapy (2nd ed.). Washington, DC: American Psychological Association

Sayar, K. (2014). Sufi psikolojisi: Bilgeliğin ruhu, ruhun bilgeliği (9th ed.). İstanbul, Turkey: Timaş Yayınları.

Shafranske, E. P., \& Malony, H. N. (1990). Clinical psychologists' religious and spiritual orientations and their practice of psychotherapy. Psychotherapy: Theory, Research, Practice, Training, 27(1), 72-78. 